jako grupa dyspozycyjna i gwarant bezpieczeństwa - ujęcie neoinstytucjonalne stała się przedmiotem badań dr. Tomasza Kołodzieja (Uniwersytet Zielonogórski). Wskazał on na strukturalne uwarunkowania zmian w zakresie zapewniania bezpieczeństwa wewnętrznego przez tę formację. Blok referatów zamknął dr Daniel Wicenty (Uniwersytet Gdański, Instytut Pamięci Narodowej) wystąpieniem Środowisko Służby Bezpieczeństwa: dyspozycyjność i funkcjonalność pod koniec PRL i u początków III RP. Z perspektywy socjologicznej dokonał analizy cech grupy, taktyk funkcjonariuszy oraz sytuacji po 1990 roku. Po części dyskusyjnej nastąpiło oficjalne zamknięcie obrad grupy tematycznej. W kolejnych dniach uczestnicy brali udział w pozostałych wydarzeniach zjazdowych, między innymi w obradach innych grup podejmujących tematykę bezpieczeństwa, a także w zebraniu Sekcji Socjologicznych Problemów Bezpieczeństwa Narodowego Polskiego Towarzystwa Socjologicznego.

Piotr Pieńkowski

ORCID: 0000-0002-1719-330X

piotr.pienkowski@uwr.edu.pl

\title{
Sprawozdanie z XVII Międzynarodowego Seminarium Metodologicznego Metodologia badań systemów społecznych, Wrocław, 12 grudnia 2019 roku
}

\section{https://doi.org/10.19195/2083-7763.10.20}

Dnia 12 grudnia 2019 roku w sali Oratorium Marianum Uniwersytetu Wrocławskiego odbyło się XVII Międzynarodowe Seminarium z cyklu Metodologia badań systemów społecznych organizowane przez Zakład Socjologii Grup Dyspozycyjnych Instytutu Socjologii Uniwersytetu Wrocławskiego, Sekcję Socjologicznych Problemów Bezpieczeństwa Narodowego Polskiego Towarzystwa Socjologicznego oraz Akademickie Koło Naukowe „Security\&Society”. Współorganizatorami byli Akadémia ozbrojených síl, Slovenska Republika, Zakład Socjologii Edukacji IS UWr i Polskie Towarzystwo Socjologiczne - Oddział Wrocławski.

Przybyło wielu znamienitych gości, między innymi: rektor Uniwersytetu Wrocławskiego prof. Adam Jezierski, dziekan Wydziału Nauk Społecznych UWr prof. Robert Wiszniowski, rektor PWSZ w Nysie prof. Przemysław Malinowski, pełnomocnik rektora PWSZ w Nysie prof. Tadeusz Iwanek, dziekan PWSZ w Raciborzu dr Sabina Musioł, dziekan PWSZ w Kaliszu prof. Jarosław Wołejszo, dziekan PWSZ w Głogowie dr Adam Bujak, dyrektor LO im. Kazimierza Jagiellończyka w Sieradzu Grzegorz Pietrucha wraz z dwiema klasami maturzystów. Należy podkreślić obecność władz lokalnych odpowiedzialnych za politykę bezpieczeństwa ekologicznego w osobach pani starosty powiatu Zduńska Wola Hanny Iwaniuk oraz prezydenta miasta Zduńska Wola Konrada Pokory, którzy aktywnie brali udział w dyskusji, wskazując na ograniczenia prawno-ekonomiczne w stosowaniu skutecznych narzędzi w walce ze smogiem. 
Tematem obrad była problematyka walki ze smogiem. Profesor dr hab. inż. Jerzy Zwoździak z Uniwersytetu Przyrodniczego we Wrocławiu wygłosił wykład Alert smogowy - edukacja społeczna przygotowany we współpracy z prof. dr hab. inż. Wiolettą Bajdur z Politechniki Częstochowskiej. W trakcie wykładu zaprezentowany został cykl zarządzania jakością powietrza. Pierwszą fazą zmian jest ustanowienie celów i strategii, następnie należy wyznaczyć stopień redukcji zanieczyszczeń. Powinno się rozwijać strategie kontroli emisji, należy też wprowadzić odpowiednie programy i na bieżąco oceniać ich skuteczność. W ten sposób - jak wnioskował prof. Zwoździak - poziom zanieczyszczeń powietrza jest możliwy do zminimalizowania. Jako przykład podana została sytuacja w Los Angeles po 1956 roku, kiedy miejsce miała „batalia antysmogowa”. W trakcie walki ze smogiem kontrolowano źródła emisji zanieczyszczeń, nakładano limity emisji na dużych przedsiębiorców i firmy. Profesor podkreślał, jak bardzo ta sytuacja była odmienna od obecnej sytuacji w Polsce - mimo że mamy pewną wiedzę na temat otaczającego nas zanieczyszczenia, nie pogłębiamy zainteresowania tematem ani nie działamy w żaden sposób, by to zmienić. Wszystko to przynosi katastrofalne wręcz efekty: przedwczesne zgony powodowane schorzeniami będącymi efektem zanieczyszczenia powietrza, niszczenie infrastruktury (przykład: Karkonosze - lasy unicestwione przez kwaśne opady), wtórne skażenie wody i gleby, a w konsekwencji nawet niedobory wody pitnej, zmiany klimatu susze, ulewy, zaburzenia mikroklimatu, zagrożenie dla bioróżnorodności prowadzące do wymierania gatunków.

W ramach przedstawienia praktycznych wymiarów walki ze smogiem doktor Adam Kruk przedstawił koreferat Realia walki ze smogiem $w$ Polsce na przykładzie dzielnicy Praga-Południe w Warszawie przygotowany we współpracy z aktorem Lesławem Żurkiem. Swój wykład rozpoczął od przytoczenia kilku fragmentów wykładu noblowskiego Olgi Tokarczuk, między innymi: „Świat umiera, a my tego nawet nie zauważamy”.

W Polsce roczny bilans przedwczesnych zgonów będących wynikiem smogu oraz powikłań zdrowotnych z nim związanych (astma, choroby układu oddechowego i krwionośnego) to około 45 tys. ofiar. Już około 30 polskich miast zapisuje się na liście pięćdziesięciu najbardziej zanieczyszczonych toksycznym powietrzem miast na świecie. Stosunek władz instytucji publicznych do tego problemu jest — zdaniem prelegenta — raczej obojętny. Przez lata trudno dostrzec jakiekolwiek znaczące działania administracyjne na rzecz poprawy stanu powietrza, a co za tym idzie - jakości życia Polaków. W celu przeciwdziałania ignorancji i niekompetencji władz oraz instytucji bezpośrednio z nimi związanych, powstał program „Pozywam Smog”. Celem tego obywatelskiego programu jest mobilizacja mieszkańców do pozywania władz miast oraz Skarbu Państwa RP do sądu, aby ten ocenił, czy, oraz w jakim stopniu, władze wywiązują się z ustawowego obowiązku dbania o zdrowie i dobro obywateli. Dopiero w wyniku masowo składanych pozwów sądowych oraz protestów, gdy okazało się, że problem zanieczyszczeń powietrza jest ważny dla zdrowia obywateli, zaczęto podejmować praktyczne działania, na przykład na terenie Mazowsza podjęto próbę legislacyjną umożliwiającą do końca 2022 roku wymianę pieców starego typu (tzw. kopciuchów) na te nowszej generacji. Dodatkowo prezydent RP Andrzej Duda podpisał ustawę zakazującą importu pieców starego typu.

Podsumowując XVII seminarium prof. Jan Maciejewski podkreślił, że to „szara” codzienność dostarcza nam wielu dowodów poświadczających, iż potrzebne są coraz to no- 
we sposoby, narzędzia oraz grupy dyspozycyjne dążące do opanowywania problemów związanych z zapewnianiem bezpieczeństwa zdrowotnego mieszkańców miast i wsi. Zmieniająca się geopolityka bezpieczeństwa wymaga ciągłego namysłu nad ujawniającymi się zagrożeniami. Dlatego w obliczu tych niekiedy nieuchronnych zagrożeń oraz towarzyszących im obaw i lęków społecznych we wrocławskim środowisku naukowym nie ustajemy w wysiłkach badawczych i edukacyjnych na rzecz wzmocnienia stanu bezpieczeństwa cywilizacyjnego potencjału.

Urszula Mazurkiewicz ORCID: 0000-0001-6579-6052 urszula.mazurkiewicz@interia.pl

Elżbieta Sypniewicz ORCID: 0000-0002-8828-4858 ela.syp@gmail.com 